\title{
NACIONALNI PARK SJEVERNI VELEBIT KAO VRHUNSKO EDUKATIVNO-TURISTIČKO SREDIŠTE
}

Dalibor Paar

Prirodoslovno-matematički fakultet

Bijenička cesta 30

HR 10000 Zagreb

dpaar@phy.hr
UDK: 338.48:502(234Velebit)

Stručni članak

10.09.2019.

Sjeverni Velebit hrvatski je biser koji u kontekstu obrazovanja 21. stoljeća, zaštite prirode, suočavanja s ugrožavanjem prirode i klimatskim promjenama može postati europski značajan edukativni centar. Osim vrednovanja, zaštite prirode i doprinosa obrazovanju, ovaj pristup može otvoriti nova radna mjesta te podići kvalitetu života lokalne zajednice. Pri tome se povezuju različiti sadržaji - obrazovni, znanstveni, kulturni, športski, zdravstveni i dr.

Suvremeno znanstveno (STEM) obrazovanje temeljeno na značajnoj georaznolikosti i bioraznolikosti može se u obliku programa ponuditi dionicima obrazovnoga sustava. Krški fenomeni Nacionalnog parka Sjeverni Velebit, posebice njegove duboke jame, jedna su od tema koja ima velike znanstveno-istraživačke i edukativne izazove.

Ključne riječi: Sjeverni Velebit, znanstveno obrazovanje, STEM, geopark, georaznolikost

\section{Uvod}

Sjeverni Velebit hrvatski je biser koji u kontekstu obrazovanja 21. stoljeća, zaštite prirode, suočavanja s ugrožavanjem prirode i klimatskim promjenama može postati europski značajan centar. Osim vrednovanja bioloških i geoloških fenomena, zaštite prirode i doprinosa suvremenom obrazovanju od vrtića do cjeloživotnog učenja, ovakav pristup otvara nova radna mjesta i podiže kvalitetu života lokalne zajednice. Za razliku od masovnog turizma gdje su obrazovne, prirodne i kulturne vrijednosti $u$ pravilu potisnute $u$ drugi plan, ovdje u prvi plan stavljamo vrhunske obrazovne programe temeljene na rezultatima aktualnih znanstvenih istraživanja. Sjeverni Velebit je lokacija koja se uz potporu europskih fondova, u sinergiji s infrastrukturnim i logističkim elementima u Krasnu, Otočcu i Senju, može razvijati na suvremenim konceptima 21. stoljeća. Iako u ovomu radu govorimo o Sjevernom Velebitu, ova priča nema granice i u dugoročnoj 
perspektivi može povezati zaštićena područja Velebita i Like te sve gradove i mjesta vezana uz Velebit.

O konceptu "UNESCO-ovog geoparka Velebit" koji obuhvaća navedene ideje intenzivnije smo počeli promišljati 2017. godine' ${ }^{1}$. Iste godine je otvorena i Kuća Velebita koja je danas jedan od najsuvremenijih edukativno-prezentacijskih centara u Hrvatskoj. Treba istaknuti da se na području drugih zaštićenih područja Velebita i Like razvijaju i implementiraju vrijedni sadržaji financiranjem prezentacijskih centara iz europskih fondova ili uvrštavanjem u UNESCOov Popis svjetske baštine kao što su na primjer bukove šume u Nacionalni park Sjeverni Velebit i Nacionalni park Paklenica ${ }^{2}$. No, ogromne promjene u obrazovanju, zaštiti prirode, znanstvenim istraživanjima koje se upravo događaju u Europskoj uniji te opcije financiranja iz europskih fondova otvaraju i puno širi spektar mogućnosti. Temeljna ideja je da se klasični turizam baziran na razgledavanju prezentacijskih materijala i šetnji poučnim stazama mijenja prema aktivnom obrazovanju i istraživanju posjetitelja. Pri tome se povezuju različiti sadržaji - obrazovni, znanstveni, kulturni, športski, zdravstveni i dr.

\section{Nacionalni parkovi i prezentacijski centri u 21. stoljeću}

U 21. stoljeću uspostavljaju se novi principi upravljanja nacionalnim parkovima i drugim zaštićenim područjima. Dolazi do temeljnih promjena u obrazovnim sustavima u smjeru znanstvenog obrazovanja $($ STEM $=$ prirodne znanosti, tehnologija, inženjerstvo i matematika), razvijaju se novi oblici turizma bazirani na edukaciji, nevjerojatno se ubrzava razvoj znanosti, istraživačkih metoda i spoznaja, a ugroženost prirode prirodnim procesima i djelovanjem čovjeka postaje sve veća. To sve zahtijeva veliku promjenu u kojoj edukativni aspekti nacionalnih parkova dolaze u prvi plan.

Suvremeno obrazovanje u Europi ima novu paradigmu u kojoj se naglasci stavljaju na svijest o ulozi znanosti u trenutačnom društvenom i globalno relevantnom kontekstu. Interes za STEM se pobuđuje u interdisciplinarnom kontekstu prirode i svakodnevnoga života. Izvanučionička, odnosno terenska nastava danas je jedan od najučinkovitijih i učenicima najdražih oblika suvremene nastave 21. stoljeća. Izlazak u prirodu, prezentacijske centre ili muzeje predstavlja jedinstven doživljaj koji se osim motiviranja i inspiriranja djece za pojedine teme pokazuje i kao učinkovit način za stjecanje trajnih znanja

${ }^{1}$ D. PAAR, 2017, 72-73.

${ }^{2}$ Ancient and Primeval Beech Forests of the Carpathians and Other Regions of Europe (2007, 2011, 2017). https://whc.unesco.org/en/list/1133m 
i vještina. ${ }^{3}$ Inovativnim i kreativnim doprinosom učitelj na danoj lokaciji može djetetu prenijeti vrhunske obrazovne sadržaje.

Nacionalni parkovi, prezentacijski centri i poučne staze predstavljaju podlogu za razvoj brojnih edukativnih sadržaja te za izvođenje istraživački, odnosno problemski orijentirane nastave. To se jasno vidi iz pregleda tema suvremenog obrazovanja u svijetu (Tab. 1). Lokacija s velikom bioraznolikošću i georaznolikošću ima neograničene mogućnosti razvoja programa kao dijelova kurikuluma ili dodatnih sadržaja u okviru neformalnog i informalnog učenja.

Tab. 1. Teme suvremenog obrazovanja za zanimanja i građane 21. stoljeća prema kojima su usmjereni najbolji obrazovni sustavi u svijetu ${ }^{4}$

\begin{tabular}{|c|c|c|}
\hline Tema & Područja ili sadržaji & Uloga u današnjem kontekstu \\
\hline $\begin{array}{c}\text { ujedinjujući koncepti i procesi } \\
\text { u prirodnim znanostima }\end{array}$ & $\begin{array}{l}\text { znanstvena metoda } \\
\text { matematika }\end{array}$ & $\begin{array}{c}\text { temelji za život i korištenje } \\
\text { tehnologija u 21. stoljeću }\end{array}$ \\
\hline fizikalne znanosti & $\begin{array}{c}\text { fizika, kemija i druga } \\
\text { područja vezana uz temeljna } \\
\text { razumijevanja prirode }\end{array}$ & $\begin{array}{c}\text { temelji STEM područja } \\
\text { eksperimentalno istraživanje } \\
\text { matematički modeli }\end{array}$ \\
\hline znanosti o životu & $\begin{array}{l}\text { biologija s brojnim granama } \\
\text { medicina, biotehnologija }\end{array}$ & $\begin{array}{l}\text { očuvanje bioraznolikosti i zaštita } \\
\text { prirode } \\
\text { razumijevanje bioloških } \\
\text { mehanizama } \\
\text { razvoj medicine i biotehnologije }\end{array}$ \\
\hline znanosti o zemlji i svemiru & $\begin{array}{l}\text { geoznanosti } \\
\text { astrofizika }\end{array}$ & $\begin{array}{l}\text { globalni geološki procesi } \\
\text { klimatski procesi } \\
\text { očuvanje georaznolikosti } \\
\text { istraživanja svemira }\end{array}$ \\
\hline $\begin{array}{l}\text { znanost u osobnom i } \\
\text { društvenom kontekstu }\end{array}$ & $\begin{array}{l}\text { znanja i vještine potrebne } \\
\text { građanima } 21 \text {. stoljeća }\end{array}$ & $\begin{array}{c}\text { informatička i financijska } \\
\text { pismenost } \\
\text { znanstveno razmišljanje }\end{array}$ \\
\hline $\begin{array}{l}\text { povijest i priroda prirodnih } \\
\text { znanosti }\end{array}$ & $\begin{array}{c}\text { prirodoznanstvenici i velika } \\
\text { otkrića kroz povijest }\end{array}$ & $\begin{array}{c}\text { motiviranje } \mathrm{i} \text { inspiriranje djece } \mathrm{u} \\
\text { smjeru stem područja }\end{array}$ \\
\hline $\begin{array}{l}\text { osnovni koncepti suvremenih } \\
\text { tehnologija }\end{array}$ & $\begin{array}{l}\text { fizikalni i kemijski koncepti } \\
\text { informatičke tehnologije }\end{array}$ & $\begin{array}{c}\text { umjetna inteligencija } \\
\text { suvremene analitičke metode i } \\
\text { uređaji } \\
\text { metode mjerenja i regulacije }\end{array}$ \\
\hline $\begin{array}{c}\text { praktično rješavanje problema } \\
\text { koristeći aktualna znanja } \\
\text { i tehnologije (inženjerski } \\
\text { pristup) }\end{array}$ & $\begin{array}{c}\text { strojarstvo } \\
\text { građevinarstvo } \\
\text { elektrotehnika i računarstvo }\end{array}$ & razvoj inženjerskih kompetencija \\
\hline
\end{tabular}

${ }^{3}$ K. PLAKITSI, 2013, 27-56; N. BUZJAK et al., 2016, 75-84.

${ }^{4}$ Ono što je ključno je da se sve navedene teme uvode od rane dobi (3. ili 4. godine života) bez obzira što će djeca kasnije raditi u životu i nadograđuju kroz cijelu obrazovnu vertikalu do cjeloživotnog učenja. 
Suvremeni prezentacijski koncepti kreću od interesa i obrazovnih potreba pojedinih skupina posjetitelja. U 21. stoljeću govorimo o istraživanju i čuđenju posjetitelja pri čemu se kroz globalno važne teme suvremenog obrazovanja prezentiraju i lokalne posebnosti. Način prezentacije je takav da posjetitelju bude zanimljiv, neobičan, neočekivan i interaktivan. Ti koncepti jedino mogu osigurati stjecanje trajnih i primjenjivih znanja. $\mathrm{Na}$ duge staze ovakav je pristup dragocjen za zaštitu prirode. Ako posjetitelji aktivno istražuju posebnosti zaštićenih područja i shvate njihov značaj na globalnoj razini, također će aktivno podržavati njihovu zaštitu.

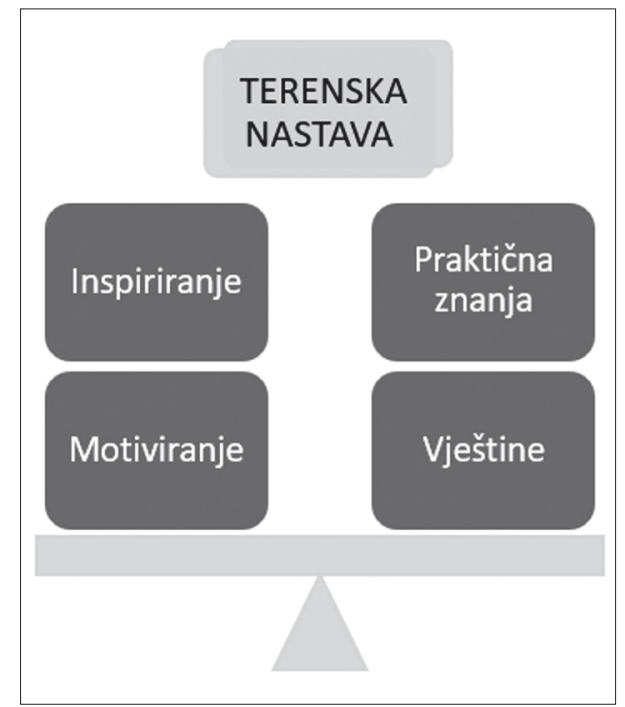

Sl. 1. Zadaci suvremene terenske nastave, autor: Dalibor Paar

\section{Sjeverni Velebit - mjesto za čuđenje i istraživanje}

Nacionalni Park Sjeverni Velebit predstavlja idealnu lokaciju za razvoj suvremenih obrazovnih programa, ali i za orijentaciju Parka u smjeru svjetski renomiranog edukativnog središta. Niz znanstvenih studija, visokokvalitetnih publikacija te poučnih sadržaja kao što su Velebitski botanički vrt i geološki poučni sadržaji te 2017. godine otvoren suvremeni prezentacijski centar - Kuća Velebita predstavljaju izvrsnu podlogu za daljnji razvoj ove vizije ${ }^{6}$. Ona se, kako ćemo istaknuti, može realizirati u okviru UNESCO-ove mreže geoparkova, no radi se i o širem konceptu koji može snažno interferirati s globalnim promjenama u obrazovanju. To pred Park postavlja izazove u vidu koordiniranja daljnjih znanstveno-istraživačkih aktivnosti od kojih se očekuju novi svjetski značajni rezultati, do zahtjevnog zadatka prezentacije istraženih posebnosti i izrade

${ }^{5}$ V. SKORUP et al., 2008.

${ }^{6}$ Projekt Kuća Velebita u Krasnu realiziran je 2017. iz Europskog fonda za regionalni razvoj. Nositelj projekta je bio Nacionalni park Sjeverni Velebit, a partner Turistička zajednica grada Senja. Projekt je koordinirala Svjetlana Lupret-Obradović, dipl. ing. biol., a u pripremi sadržaja su, uz stručnjake Parka, sudjelovale grupe znanstvenika iz niza znanstvenih ustanova i fakulteta. Poseban doprinos geološkom dijelu postava i njegovim dopunama dala je Dubravka Kljajo, dipl. ing. geol. 


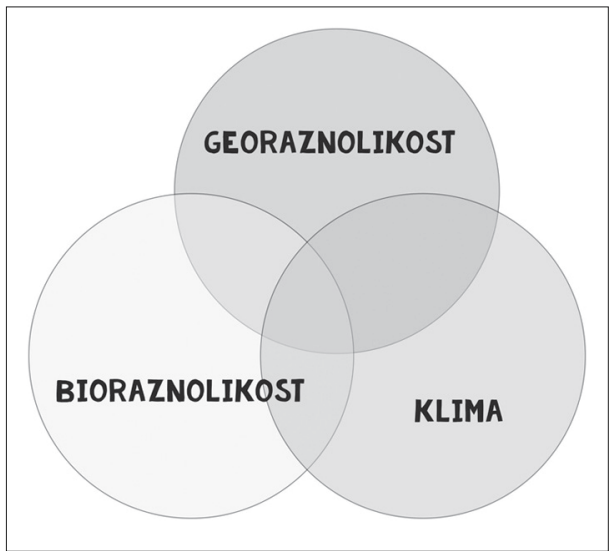

S1. 2. Zaštita prirode podrazumijeva istraživanje georaznolikosti,

bioraznolikosti i praćenje klimatskih značajki na danoj lokaciji, autor: Dalibor Paar

interdisciplinarnih edukativnih programa.

Velebit je od 1978. UNESCOov rezervat biosfere te od 1981. park prirode. 1949. je osnovan Nacionalni park Paklenica, a 1999. Nacionalni park Sjeverni Velebit. Velebit je u cijelosti dio ekološke mreže $E U$ Natura 2000, što jasno upućuje na širi globalni značaj ${ }^{7}$. Velebit je najznačajnije endemsko područje flore i kopnene faune u RH. Osim njegove izuzetne bioraznolikosti, odlikuje ga i georaznolikost čije se značajke intenzivno utvrđuju posljednjih desetljeća. Nakon otkrića kojih se dotičemo i u ovom radu jasno je da o Velebitu ne možemo raspravljati bez detaljne diskusije o geologiji i klimi koje s biološkim vrijednostima čine izuzetan ekosustav.

Georaznolikost je relativno novi alat koji se intenzivno razvija u ovom tisućljeću i kojim se nastoji definirati kompleksnost prirodnih vrijednosti pojedinog područja na svim razinama, razumjeti njihove odnose i u konačnici definirati sveobuhvatne strategije bazirane na njima, legislativu, upravljanje i zaštitu. Georaznolikost je okvir za jasno definiranje znanstvenog i edukativnog statusa geobaštine. ${ }^{8}$ U 20. stoljeću, uvođenjem koncepata bioraznolikosti, abiotički aspekti prirode bili su potisnuti iz zaštite prirode ili samo svedeni na pozadinski faktor koji utječe na okolišne uvjete koji su bitni za žive organizme. Danas se u kontekstu klimatskih promjena, ali i potrebe očuvanja geoloških osobitosti uvođenjem georaznolikosti definira novi pristup u kome će se uvažiti kompleksnost i povezanost pojedinih prirodnih vrijednosti i okolišnih uvjeta. Georaznolikost kao varijabilnost Zemljinih površinskih materijala, formi i fizikalnih procesa integralni je dio prirode i kritična je za očuvanje ekosustava i njihovih servisa. ${ }^{9}$

\footnotetext{
${ }^{7}$ Z. ŠIKIĆ et al., 2017, 17-34.

${ }^{8}$ L. ERIKSTAD, 2013, 713.

${ }^{9}$ J. HJORT et al., 2015, 630.
} 


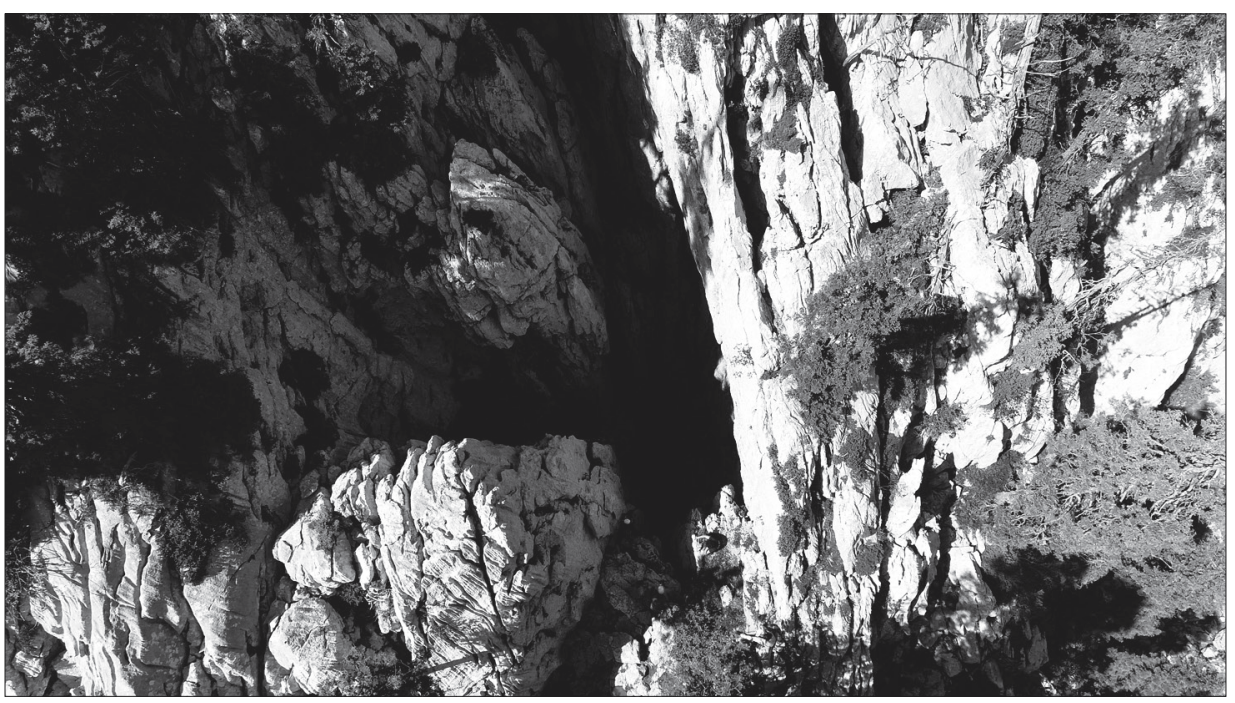

Sl. 3. Ulaz u Lukinu jamu. Jamski sustav Lukina jama - Trojama dubine $1431 \mathrm{~m}$ najdublji je u Dinarskom kršu. Ulaz se nalazi u vrlo zanimljivim velebitskim vapnenačkim brečama koje su tema aktualnih geoloških studija. Foto: Dalibor Paar

Podzemlje Velebita, odnosno njegove brojne speleološke pojave predstavljaju izvrstan primjer zašto je nužno povezati geološke, biološke i klimatske aspekte. Speleološka istraživanja Sjevernog Velebita izvode se još od 1930. godine. ${ }^{10}$ Novi zamah istraživanja kreće od 1992. godine i otkrića $1431 \mathrm{~m}$ dubokog jamskog sustava Lukina jama - Trojama ${ }^{11}$.

Otada se speleološkim istraživanjima svake godine dopunjuje slagalica kompleksnih podzemnih krških fenomena Sjevernog Velebita. To je rezultiralo istraživanjem mnogih dubokih jama: 1324 m duboke Slovačke jame ${ }^{12}, 1026$ m dubokog Jamskog sustava Velebita i još 6 jama dubljih od $500 \mathrm{~m}$. Da se intenzitet istraživanja ne smanjuje, pokazuju rezultati 2019. godine kada se u jami Nedam na Hajdučkim kukovima prošlo dubinu od 920 m. Do 2019. istraženo je više od 500 speleoloških objekata na području Sjevernog Velebita, što predstavlja izuzetnu gustoću na relativno malom području. Posebnost jama Sjevernog Velebita su dugačke vertikale. U Jamskom sustavu Velebita otkrivena je vertikala dugačka $513 \mathrm{~m}$, a to je čini jednom od najduljih podzemnih vertikala na svijetu ${ }^{13}$.

${ }^{10}$ V. BOŽIĆ, 2002, 343.

${ }^{11}$ D. BAKŠIĆ et al., 2013, 24-29; http://speleologija.eu/lukinajama

${ }^{12}$ D. BAKŠIĆ et al., 2000, 5-14; http://speleologija.eu/slovacka/

${ }^{13} \mathrm{http}: / /$ speleologija.eu/velebita/ 


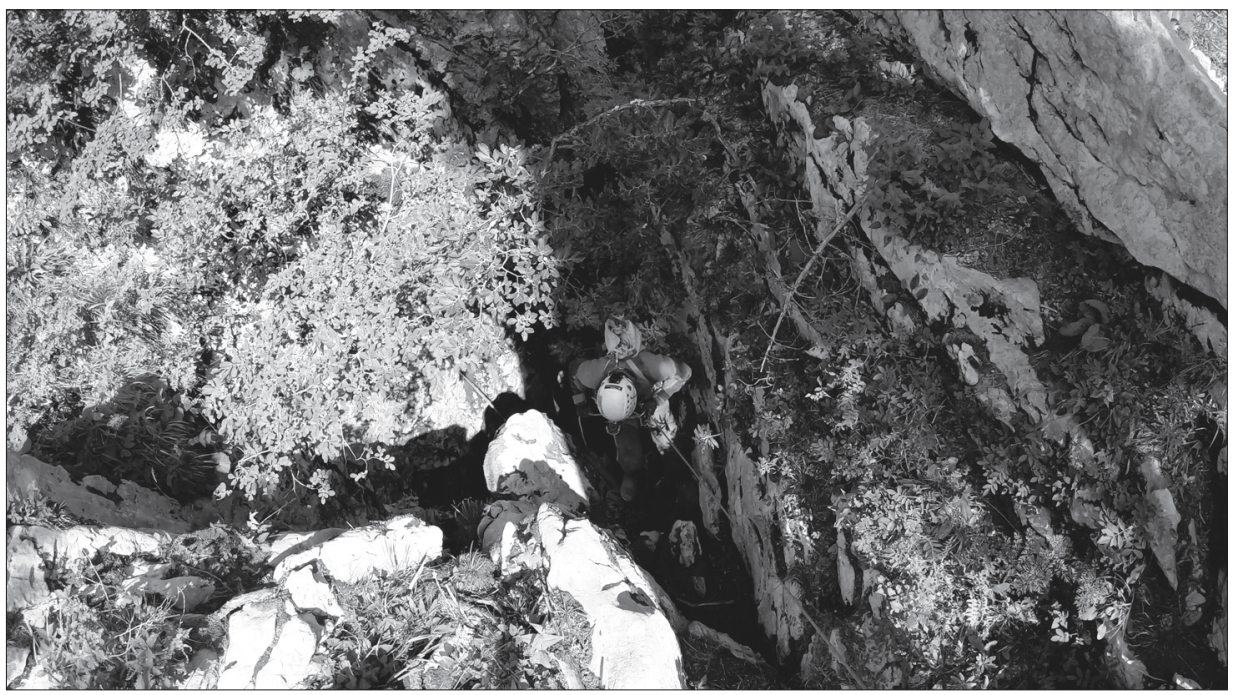

S1. 4. Ulaz u jamu Nedam. Jamu su otkrili članovi Speleološkog odsjeka PDS Velebit 1997. godine kada se došlo do 247 m dubine. Intenzivnim speleološkim istraživanjima 2019. godine došlo se do 920 m dubine i trenutačno je četvrta po dubini jama u Hrvatskoj. Istraživanja se nastavljaju. Foto: Dalibor Paar

Posebno je zanimljiv led koji je zabilježen u više od stotinu jama i zadržava se tijekom cijele godine te se proteže do dubina i iznad $500 \mathrm{~m}$.

Činjenica da je najveći dio speleoloških objekata dostupan samo speleolozima predstavlja izazov na koji način posjetitelja upoznati s podzemnim prirodnim bogatstvom Sjevernog Velebita. Jedan od koraka u tom smjeru je dio postava u Kući Velebita koji bi trebalo još znatno proširiti sadržajima na samom terenu. Lokacija pogodna za nove edukativne programe je Varnjača, jama do koje je u prošlom stoljeću postojao uređeni planinarski put. Ona bi bez puno intervencija u prostoru mogla postati jedinstvena učionica o prirodi i zaštiti dubokih jama i drugih krških fenomena ${ }^{14}$.

Kontinuiranim speleološkim istraživanjima prikupljaju se podaci i prati stanje u podzemlju koje je izravno ovisno o uvjetima na površini. Na taj način se detektiraju promjene bitne za podzemni i nadzemni ekosustav. ${ }^{15}$ Neka od pitanja na koja se nastoji odgovoriti su koji je uzrok povišenih koncentracija teških metala $\mathrm{i}$ drugih elemenata na velikim dubinama ${ }^{16}$, kakav je kemizam vode $\mathrm{i}$

${ }^{14}$ D. PAAR et al., 2015, 37.

${ }^{15}$ G. RNJAK, 2019, 789.

${ }^{16}$ D. PAAR et al., 2016, 20-37. 


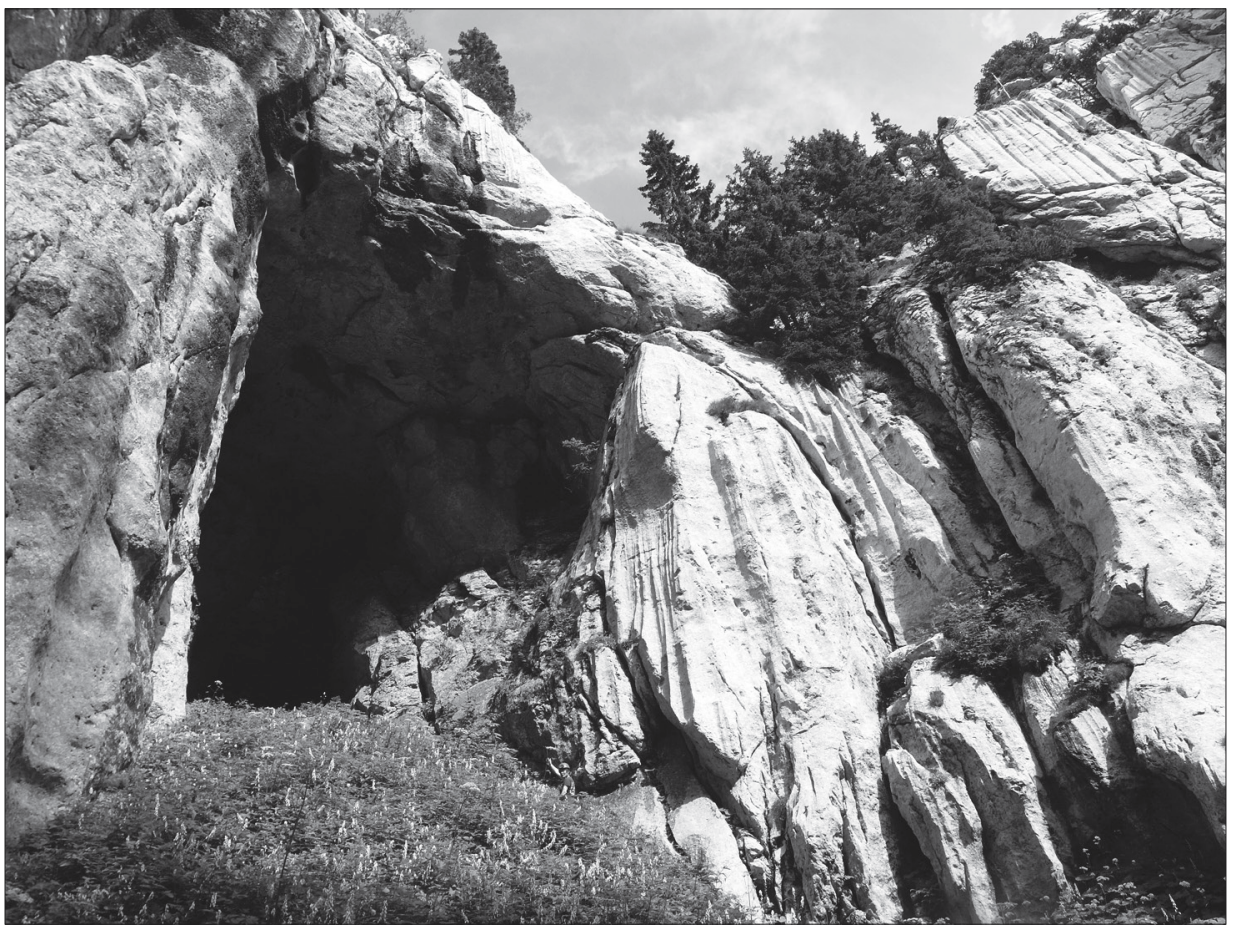

Sl. 5. Jama Varnjača je izvrsna speleološka lokacija na Sjevernom Velebitu koja bi bila pogodna za izvođenje edukativnih programa fokusiranih na georaznolikost i klimu. Foto: Dalibor Paar

njezina interakcija sa stijenama i sedimentima, što se zbiva u vadoznoj i freatičkoj zoni (iznad i ispod razine voda), kakva je dinamika voda u podzemlju, koje je porijeklo i smjer kretanja tih voda. Prisutnost leda, za koji postoje pretpostavke da se u jamama nalazi od zadnjeg malog ledenog doba u Europi i koji nalazimo na, prema svjetskim mjerilima, značajnim dubinama otvara brojne mogućnosti i pitanja u okviru proučavanja klimatskih promjena i mikroklime jama ${ }^{17}$.

Uz brojne geomorfološke značajke dubokih jama koje uključuju posebnost i preko pola kilometra dugačke vertikale te dvorane na velikim dubinama, ustanovljena je kompleksna geološka slika dubokih jama. Posebnu temu pritom čine velebitske vapnenačke breče, globalno značajan geološki fenomen koji je tema aktualnih geoloških studija. Pretpostavlja se da su nastale u vrijeme jakih tektonskih aktivnosti kada se čitavo "pravelebitsko" područje počelo izdizati

${ }^{17}$ N. BUZJAK et al., 2018, 335-369. 


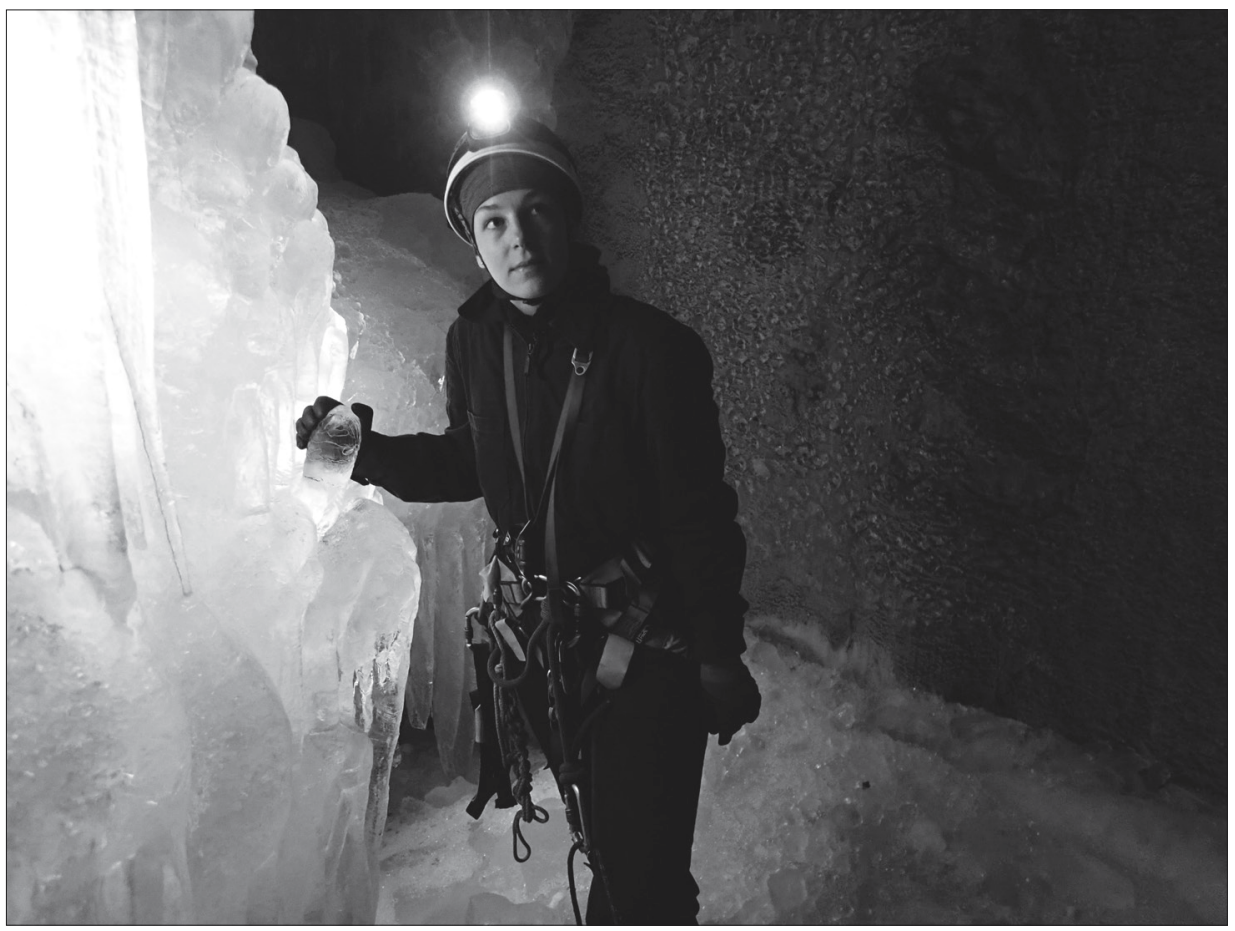

S1. 6. Ledena dvorana u Lukinoj jami na $60 \mathrm{~m}$ dubine snimljena u kolovozu 2019. godine. U nizu jama opaženo je spuštanje razine stalnog leda za preko pola metra u odnosu na prethodnu godinu. Foto: Dalibor Paar

taloženjem ulomaka nastalih lomljenjem, okršavanjem i drobljenjem već ranije izdignutih naslaga ${ }^{18}$. Zahvaljujući istraživanjima dubokih jama Sjevernog Velebita ustanovljeno je da su velebitske breče debljine i preko $500 \mathrm{~m}^{19}$.

Biospeleološkim istraživanjima u speleološkim objektima Sjevernog Velebita ustanovljene su brojne vrste, od čega 5 endema ${ }^{20}$. Prisutnost endemne špiljske faune na velikim dubinama otvara brojna pitanja o uvjetima koji su omogućili razvoj na tim dubinama te je li i kada postojala poveznica vrsta koje se nalazi u različitim jamama Velebita, ali i na puno daljim lokacijama.

${ }^{18}$ I. VLAHOVIĆ et al., 2018, 201; J. VELIĆ et al., 2017, 77-96.

${ }^{19}$ A. STROJ - D. PAAR, 2019, 553.

${ }^{20}$ To su Meštrovljeva pijavica (Croatobranchus mestrovi) iz Lukine jame - Trojame, puž pod imenom kupolasti špiljaš (Zospeum tholussum), dvokrilac špiljska hajdi (Troglocladius hajdi) te kornjaši Casaleov filtrator (Croatodirus casalei) i Šmidin filtrator (Velebitodromus smidai) koji su opisani iz Slovačke jame; P. BREGOVIĆ - T. ROŽMAN, 2018. 


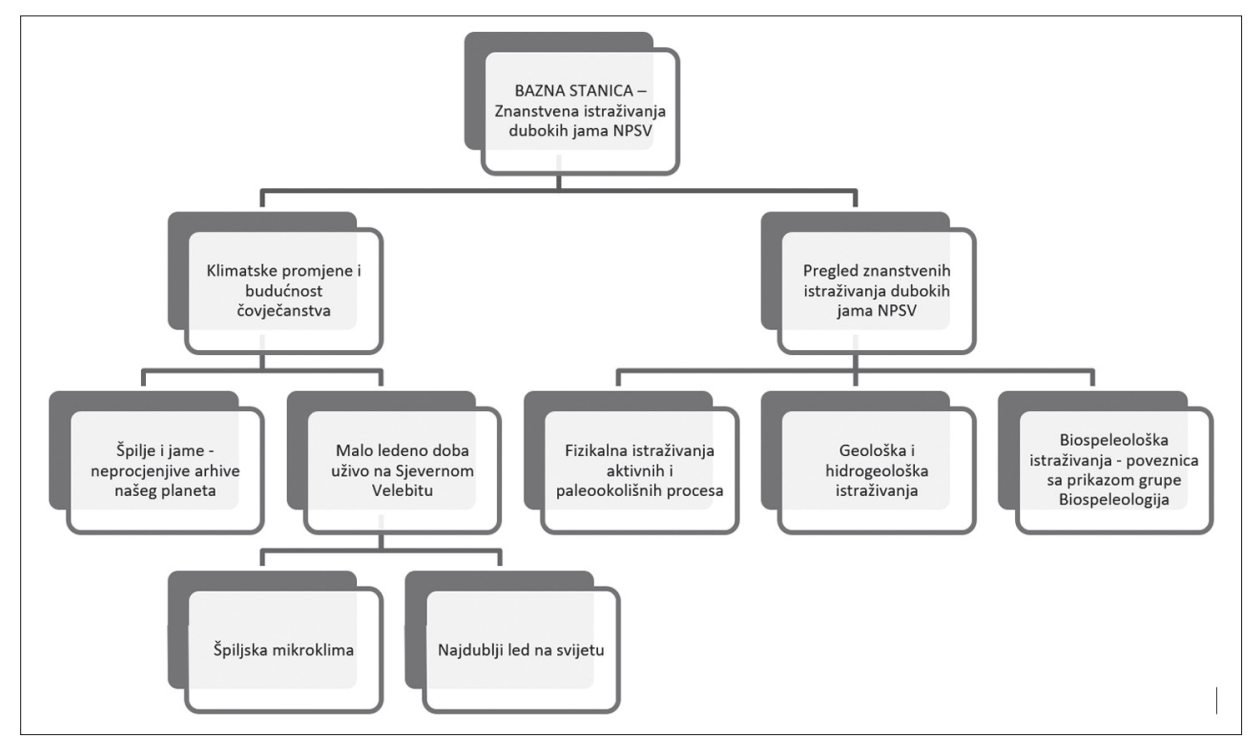

Sl. 7. Koncept prikaza dubokih jama Sjevernog Velebita u postavu Kuće Velebita s fokusom na njihove speleološke i geološke značajke, autor: Dalibor Paar

Istraživan je i biljni svijet u ulaznim dijelovima jama (speleoflora) koji se razvija uz specifične ekološke uvjete ${ }^{21}$. Ovo su samo neka od znanstvenih pitanja na kojima se uz podršku Parka dosad radilo i koja dugoročno mogu Park pozicionirati kao znanstveno-edukativni centar. U postavu Kuće Velebita ova pitanja su razrađena u tom smjeru otvarajući mogućnosti za suvremene obrazovne programe (S1. 6. i 7.). ${ }^{22}$

UNESCO-va mreža geoparkova po svojoj je definiciji okvir koji spaja znanstvene i edukativne komponente i razvija mehanizme za njihov razvoj i implementaciju u programe i upravljanje. Zbog toga bi strateški cilj Parka trebao biti uključivanje u tu mrežu uz daljnje poticanje speleoloških i pratećih interdisciplinarnih znanstvenih istraživanja posebno usmjerenih na duboke jame i površinsku geologiju Parka. Pritom je temeljna odrednica da se edukativni programi neprestano razvijaju i dopunjavaju najnovijim otkrićima. Bitno je i tko razvija programe. To trebaju biti sami istraživači Velebita u suradnji s ključnim dionicima obrazovnog sustava, nastavnicima u školama i na fakultetima. Cilj tih programa je, koristeći svjetske posebnosti Parka, motivirati posjetitelja na upoznavanje širih i danas aktualnih znanstveno-

${ }^{21}$ S. BUZJAK, 2001, 162.

${ }^{22}$ D. BAKŠIĆ et al., 2016. 


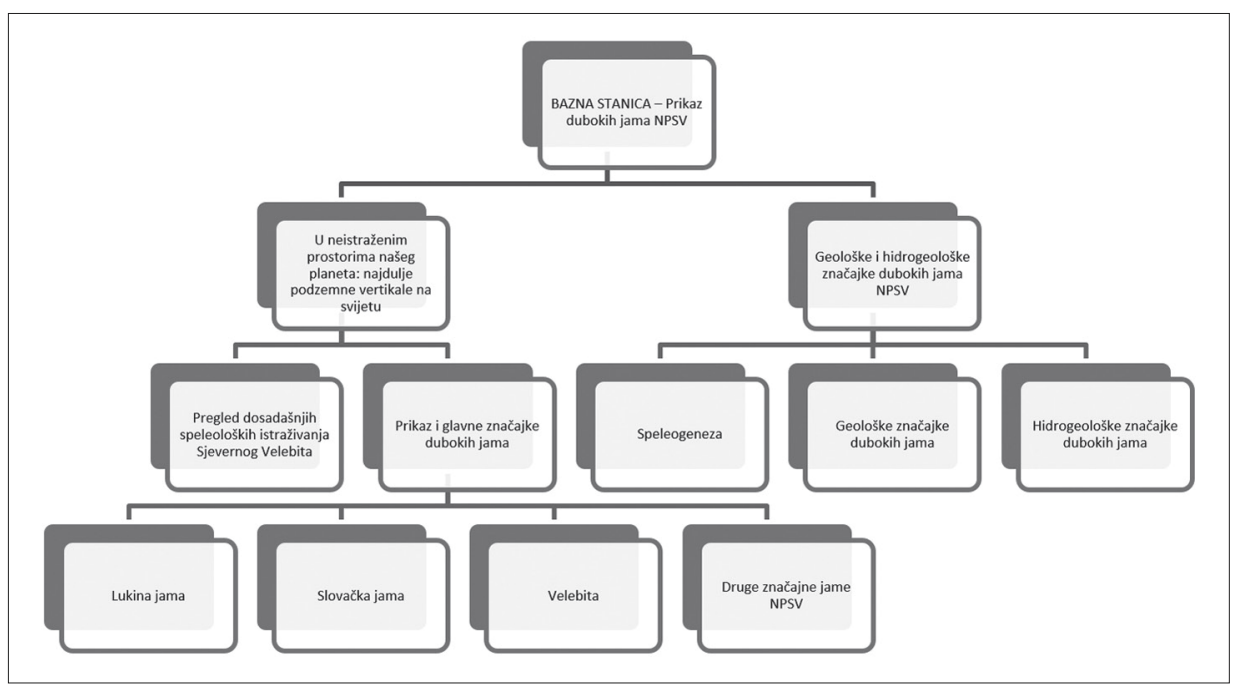

Sl. 8. Teme znanstvenih istraživanja dubokih jama Sjevernog Velebita u postavu Kuće Velebita na kojima se mogu razvijati suvremeni obrazovni sadržaji povezani s poviješću našeg planeta, klimatskim promjenama, paleookolišnim procesima i drugim temama, autor: Dalibor Paar

edukativnih sadržaja. Istovremenim pokrivanjem širih tema iz školskog kurikuluma Park se može pozicionirati unutar modernog obrazovnog sustava, čime zaokružuje svoju ulogu.

\section{Zaključak}

Visoka razina neistraženosti krških fenomena Nacionalnog parka Sjeverni Velebit i potencijali za nova otkrića otvaraju brojne mogućnosti generiranja dinamičnih edukativnih sadržaja koji se mogu neprestano dopunjavati kroz kontinuiranu suradnju sa stručnjacima. Za privlačenje posjetitelja, ali i svojevrsnu reklamu Parka korisno je periodički objavljivati nova saznanja, ali i osmišljavati programe koji pred posjetitelje stavljaju nove izazove koji u njima pobuđuju znatiželju, potiču ih na samostalno istraživanje i učenje kako bi ostvarili cilj koji se pred njih postavi. Dinamičnost sadržaja posjetitelje privlači da više puta posjete lokaciju, a obrazovne ustanove motivira da učenicima ili studentima pruže direktan uvid u otkrića ili ih izlože poticajnom okolišu. Iako je bitna, zaštita nije jedina kvaliteta kojoj edukacija o prirodi treba težiti, pa bi naglasak u 21. stoljeću trebao biti na razumijevanju prirodnih mehanizama, iz kojih proizlaze benefiti šireg opsega, pa i zaštita. Otkriće dotad nepoznatoga, 


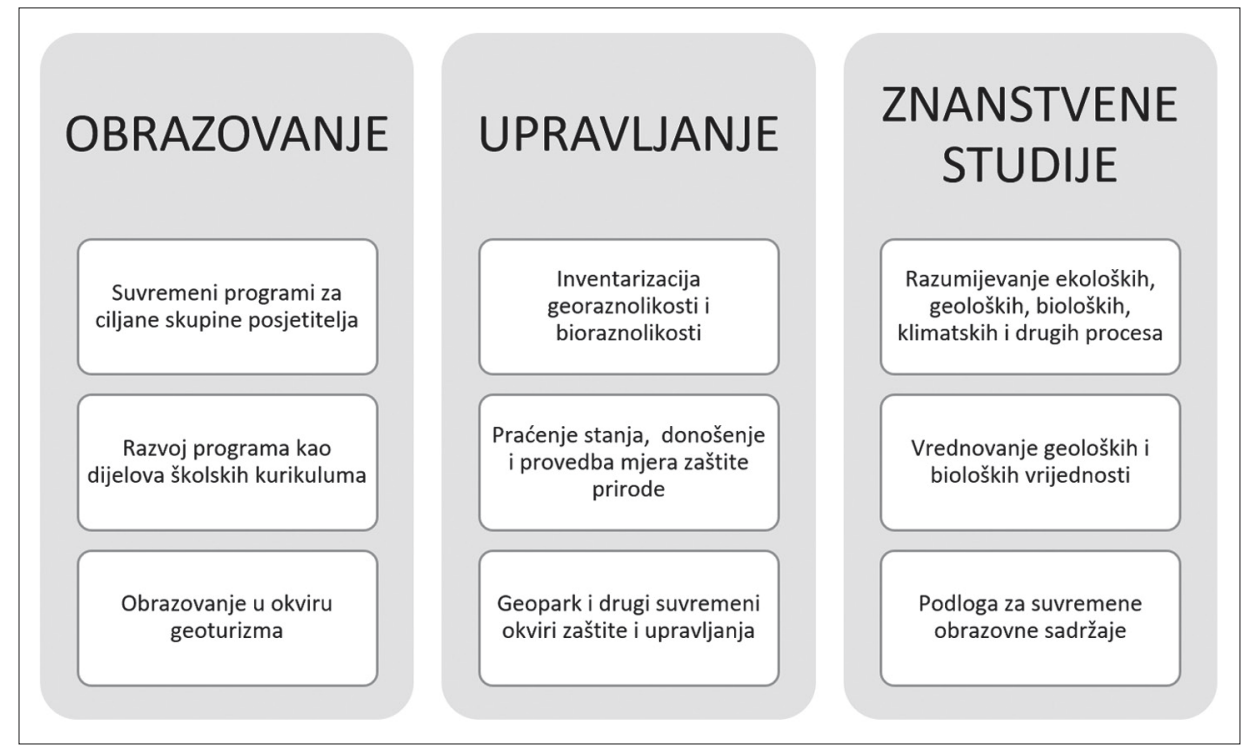

S1. 9. Vizija Nacionalnog parka Sjeverni Velebit u 21. stoljeću, autor: Dalibor Paar

neobičnoga i neočekivanoga je nešto što uz odgovarajuće prezentacijske tehnike učenicima i studentima može pobuditi interes za prirodne znanosti, odnosno sukladno s preporukama Europske komisije ${ }^{23}$ pobuditi interes za znanstveno obrazovanje i STEM područja.

\section{Literatura}

Darko BAKŠIĆ - Branko JALŽIĆ - Damir LACKOVIĆ, Slovačka jama na Sjevernom Velebitu, Senjski zbornik, 27, Senj, 2000, 5-14.

Darko BAKŠIĆ - Dalibor PAAR - Andrej STROJ - Damir LACKOVIĆ, Northern Velebit Deep Caves, 16th International Congress of Speleology, 2, Brno, 2013, 24-29.

Darko BAKŠIĆ - Damir LACKOVIĆ - Dalibor PAAR - Andrej STROJ, Centar za posjetitelje - Kuća Velebita, Krasno. Koncept postava: Grupa II. Speleologija, Krasno, 2016.

Vlado BOŽIĆ, Duboke jame Sjevernog Velebita, Senjski zbornik, 29, Senj, 2002, 343360 .

\footnotetext{
${ }^{23}$ E. HAZELKORN, 2015.
} 
Nenad BUZJAK - Neven BOČIĆ - Dalibor PAAR, Terenska nastava u stručnom usavršavanju učitelja i nastavnika geografije, Geografski horizont, 61 (2), Zagreb, 2016, 75-84.

Nenad BUZJAK - Neven BOČIĆ, Dalibor PAAR - Darko BAKŠIĆ - Vinka DUBOVEČAK, Ice Caves in Croatia, u: Ice Caves, ur. Aurel Persoiu i Stein-Erik Lauritzen, Amsterdam, 2018, 335-369.

Suzana BUZJAK, Ekološka i floristička obilježja ulaznih dijelova jama i spilja u kršu Hrvatske, Doktorska disertacija. Zagreb, 2001.

Lars ERIKSTAD, Geoheritage and geodiversity management - the questions for tomorrow, Proceedings of the Geologists' Association, 124, 2013, 713-719.

Ellen HAZELKORN (ed.), Report to the European Commission of the Expert Group on Science Education. Science Education for Responsible Citizenship. European Union, 2015.

Jan HJORT - John E GORDON - Murray GRAY - Malcolm L HUNTER, Why geodiversity matters in valuing nature's stage, Conserv Biol., 2015, 630-639.

Dalibor PAAR - Stanislav FRANČIŠKOVIĆ-BILINSKI - Nenad BUZJAK Krešimir MALDINI - Simana MILKOVIĆ - Srđan PICHLER, Geochemical and mineralogical characterization of speleothems from the karst of Croatia as potential sources of data for environmental researches, Journal of geochemical exploration, 167, 2016, 20-37.

Dalibor PAAR, NP Sjeverni Velebit - edukativno središte. Znanstveno-stručni skup "Od istraživanja $k$ dobrom upravljanju Nacionalnim parkom Sjeverni Velebit", Krasno, 2017.

Dalibor PAAR - Vinka DUBOVEČAK - Dubravka KLJAJO, Koncept poučne staze "Jama Varnjača" u NP Sjeverni Velebit, Međunarodni znanstveno-stručni skup "Georaznolikost, geobaština i geoturizam u krškim područjima", Perušić, 2017.

Katerina PLAKITSI, Teaching Science in Science Museums and Science Centers Towards a New Pedagogy?, Activity Theory in Formal and Informal Science Education, 2013, 27-56.

Goran RNJAK (ur.), Speleologija, Zagreb, 2019.

Vlatko SKORUP - Sanja KOVAČIĆ - Dario KREMER - Darko MIHELJ, Velebitski botanički vrt-oaza na 1500 m-vodič, Krasno, 2008.

Andrej STROJ - Dalibor PAAR, Water and air dynamics within a deep vadose zone of a karstmassif: Observations from the Lukina jama-Trojama cavesystem (-1, 431 m) in Dinaric karst (Croatia), Hydrological processes, 33, 2019, 551-561.

Zoran ŠIKIĆ - Denis GURLICA - Tomislav ŠARIĆ, Velebit i zaštita prirode, Senjski zbornik, 44, Senj, 2017, 17-34.

Ivo VELIĆ - Josipa VELIĆ, Od morskih plićaka do planine: Geološki vodič kroz Nacionalni park Sjeverni Velebit, Krasno, 2009.

Josipa VELIĆ - Ivo VELIĆ - Dubravka KLJAJO - Ksenija PROTRKA - Hrvoje ŠKRABIĆ - Zlatko ŠPOLJAR, A geological overview of glacial accumulation 
and erosional occurrences on the Velebit and the Biokovo Mts., Croatia, The Mining-Geology-Petroleum Engineering Bulletin, Zagreb, 2017, 77-96.

Igor VLAHOVIĆ - Ivo VELIĆ - Bruno TOMLJENOVIĆ - Bojan MATOŠ - Paul ENOS, Massive Cenozoic carbonate breccia in the Karst Dinarides of Croatia, u: Advances of Geology in southeast European mountain belts, ur. Franz Neubauer, Uwe Brendel i Gertrude Friedl, Sofia, 2018.

\section{Internetski izvori}

Ancient and Primeval Beech Forests of the Carpathians and Other Regions of Europe (2007, 2011, 2017). URL: https://whc.unesco.org/en/list/1133 (2019-09-06).

Petra BREGOVIĆ - Tin ROŽMAN, Biospeleološka istraživanja Nacionalnog parka

Sjeverni Velebit. URL: http://www.np-sjeverni-velebit.hr/novosti/?p=7 (201809-10)

http://speleologija.eu/lukinajama (2019-09-04).

http://speleologija.eu/slovacka (2019-09-04).

http://speleologija.eu/velebita/ (2019-09-04).

\section{NORTHERN VELEBIT NATIONAL PARK AS A SUPERB EDUCATIONAL-TOURIST CENTRE}

\section{Summary}

Northern Velebit is a Croatian pearl which in the context of education in the $21^{\text {st }}$ century, nature protection, confronting the endangerment of nature and climatic changes could become a significant European centre. Besides the evaluation, protection of nature and contribution to education from the nursery to lifelong learning, the development in this direction opens new workplaces and raises the quality of life of the local community. The Northern Velebit National Park is a location which in synergy with the infrastructure and logistic elements in Kras, Otočac and Senj, along with the support of European funds, can develop on contemporary educational concepts of the $21^{\text {st }}$ century.

Especially the underground of Velebit, in other words, its numerous speleological phenomena, represent an excellent example of why it is necessary to connect the geological, biological and climatic aspects of the protected location.

The high level of unexplored karst phenomena of the Northern Velebit National Park and the potentials for new discoveries open the possibilities of generating dynamic educational contents which can be supplemented through continuous collaboration with experts. The discovery of something new until then unknown, unusual and unexpected is something which with the corresponding presentation techniques can awaken interest in the natural sciences in pupils and students, in other words, in accordance with the recommendations of the European Commission awaken the interest in the education of science and STEM regions.

Keywords: Northern Velebit, education of science, STEM, geopark, geodiversity 